\title{
Futbol Hakemlerinin Zihinsel Dayanıklılık ve Örgüte Bağlılık İlişkisinde Öz Yeterliğin Aracılık Rolü ${ }^{1}$
} (Araştırma Makalesi)

\author{
The Mediating Role of Self-Efficacy in the Relationship Football Referees's \\ Mental Toughness and Organizational Commitment
}

Doi: 10.29023/alanyaakademik.869477

\author{
Altan ÖZCAN \\ Mezun, Süleyman Demirel Üniversitesi, SBE, Işletme ABD \\ altanozcan1@gmail.com \\ Orcid No: 0000-0002-3642-1910
}

\section{Gaye ATILLA}

Doç. Dr., Süleyman Demirel Üniversitesi, IIIBF, İşletme Bölümü

gayeatilla@sdu.edu.tr

Orcid No: 0000-0003-1421-917X

Bu makaleye atıfta bulunmak için: Özcan, A. \& Atilla, G. (2021). "Futbol Hakemlerinin Zihinsel Dayanıklılık ve Örgüte Bağlllık İlişkisinde Öz Yeterliğin Aracılık Rolü”. Alanya Akademik Baklş, 5(2), Sayfa No.815-837.

\section{Anahtar kelimeler: \\ Futbol Hakemleri, Zihinsel Dayanıklılı, Örgüte Bă̆lllık, $\ddot{O} z$ Yeterlik.}

Makale Geliş Tarihi: 27.01.2021

Kabul Tarihi: 28.04.2021

Keywords:

Football Referees, Mental Toughness, Organizational Commitment, Self-Efficacy

\section{ÖZET}

Çalışmanın amacı, futbol hakemlerinin zihinsel dayanıklılık ve örgüte bağlllık arasındaki ilişkide öz yeterliğin aracılık rolünü incelemektir. Araştırmanın evreni 2018-2019 futbol sezonunda Antalya, Isparta ve Burdur illerinde farkl klasmanlarda görev alan faal futbol hakemlerinden, örneklemi ise Antalya, Burdur ve Isparta illerinde il ve aday hakem statüsünde bulunan 235 faal futbol hakeminden oluşmaktadir. Araştırmada veri toplama aracı olarak anket tekniği kullanılmıştır. Anket formunun oluşturulmasında kişisel bilgi formu, Sporda Zihinsel Dayanıklılık Envanteri, Örgüte Bă̆lllık Ölçeği ve Hakem Öz Yeterlik Ölçeği'nden yararlanılmıştır. Araştırma sonucunda elde edilen bulgular SPSS 22.0 istatistik paket programında değerlendirilmiştir. Yapılan analizler sonucunda değişkenler arasında pozitif yönlü anlamlı ilişkiler bulunmuştur. Zihinsel dayanıklılı̆̆ın örgüte bă̆lılık üzerindeki etkisinde öz yeterliğin "kısmi aracılık” rolü üstlendiği tespit edilmiştir.

\begin{abstract}
The aim of the study is to investigate the mediating role of self-efficacy in the relationship between mental toughness and organizational commitment of football referees. The population of the study consists of active football referees in different classifications in Antalya, Burdur and Isparta provinces during the 2018-2019 football season. The sample of the study consists of 235 active football referees in Antalya, Burdur and Isparta provinces. The questionnaire technique was used as a data collection tool. Personal
\end{abstract}

\footnotetext{
${ }^{1}$ Bu çalıșma SYL-6911 numaralı proje ile Süleyman Demirel Üniversitesi Bilimsel Araştırma Projeleri Koordinasyon Birimi tarafından desteklenen "Futbol Hakemlerinin Zihinsel Dayanıklılık ve Örgüte Bağlılık İlişkisinde Öz Yeterliğin Aracılık Rolü” başlıklı yüksek lisans tezinden türetilmiştir.
} 
information form, Inventory of Mental Toughness in Sports, Organizational Commitment Scale and Referee Self-Efficacy Scale were used in creating the questionnaire. The findings of the research were evaluated in SPSS 22.0 statistical package program. As a result of the analyzes, positive significant relationships were found between variables. The effect of mental toughness on the organization commitment has been determined that self-efficacy plays a partial mediation role.

\section{GİRIŞ}

Yaşamın en önemli sosyal olgularından biri olan spor, ekonomiye dayalı sektörlerden biri olarak gelişimini devam ettirmektedir. Futbol, günümüzde kitleleri arkasından sürükleyen, birçok kişi tarafından sevilen ve ilgiyle takip edilen popüler bir spor dalıdır. Son yıllarda ekonomik gelişmelerle birlikte futbol, dünyanın en büyük endüstrilerinden biri haline gelmiştir. Futbolun yönetiminde önemli aktörlerden biri de hakemlerdir. Bu oyunu yöneten hakemlerin eğitimleri, fiziksel ve zihinsel durumları, ekonomik ve sosyo-kültürel düzeyleri ve de klasman seviyeleri gibi bazı faktörler açısından farklılık göstermektedir. Hakemlerin maç yönetimlerinin tartışılması konunun öz yeterlikle ilişkili olabileceğini düşündürmektedir.

Futbol hakemleri yoğun baskı ve stres altında performans göstermektedir. Wood ve Bandura (1989) öz yeterlik ile performans ilişkisine vurgu yapmaktadır. Öz yeterlik, "bireyin kendisinden beklenen durumları yönetmesini sağlayacak yeteneklere olan inancı" şeklinde ifade edilmiştir (Bandura, 1995). Oynanan müsabakanın skoruna ve gidişatına büyük etkisi olduğu düşünülen hakemlerin fiziksel ve zihinsel durumlarının verdikleri kararlara yüksek düzeyde etki ettiği düşünülmektedir. Bu bakımdan fiziksel yeterliklerinin yanında zihinsel olarak dayanıklı olmaları son derece önem arz etmektedir. Sheard (2013)'a göre zihinsel dayanıklılık: ilgili hedefleri gerçekleştirmek için sorumluluk alma ve mücadele etme özelliklerini taşımaktadır. Clough vd., (2002) tarafından yapılan araştırmada zihinsel dayanıklılığın '4C' (Control, Challenge, Commitment, Confidence) dört temel unsurdan meydana geldiği belirtilmektedir. Bu bağlamda commitment (bağlılık) unsuru örgüte bağl1lık kavramı ile ilişkilendirilebileceği öngörülmektedir.

Yapılan literatür incelemeleri sonucunda zihinsel dayanıklılık ve hakem öz yeterliğine ilişkin oldukça sınırlı sayıda araştırma bulunmuş, ancak burada kullanılan üç değişkenin birlikte incelendiği herhangi bir çalışmaya rastlanmamıştır. Bu, çalışmanın özgün yanıdır. Zihinsel dayanıklılık, örgüte bağlılık ve hakem öz yeterliği değişkenlerini aynı modelde incelemesi bakımından yazında yenidir. Ayrıca hakem öz yeterliğinin aracılık rolüne ilişkin de literatürde bir boşluk bulunmaktadır. Zihinsel dayanıklılık ve örgüte bağlılık ilişkisinde öz yeterliğin kısmi aracılık rolünün bulunması başka değişkenlerin aracılık etkisinin bulunabileceğine işaret etmektedir. Sonuç olarak bu araştırmada elde edilen bulguların literatüre önemli katkısı olacağı düşünülmektedir.

Bu çalışma üç bölümden oluşmaktadır. İlk olarak kavramsal çerçeve kapsamında öz yeterlik, hakem öz yeterliği, zihinsel dayanıklılık, hakemlikte zihinsel dayanıklılık ve örgüte bağlılık kavramları hakkında bilgilere yer verilmiştir. İkinci olarak araştırmanın yöntemi ele alınmıştır. Üçüncü ve son olarak araştırmanın bulguları yorumlanmıştır.

\section{KAVRAMSAL ÇERÇEVE}

\section{1. Öz Yeterlik}


Bireyler duygu, düşünce ve davranışlarını karşılıklı etkileşimle şekillendirirler. Davranışlarını şekillendirmek için gözlemlemeyi temel öğrenim süreci olarak belirten görüş Aristo ve Plato'ya kadar dayanmaktadır (Peker, 2018: 7). John Dewey, insanların birbirinden öğrenme olgusunu ilk belirten isim olmuştur. Sosyal etkileşim doğrultusunda birey düşüncelerini ve deneyimlerini paylaşarak kendi belleğini şekillendirir. Sosyal öğrenme kavramını ilk kullanan kişi Julian Rotter olmuştur. Günümüzde sosyal öğrenme teorisinden bahsederken ilk akla gelen isim Albert Bandura'dır. 1960'lı yıllarda Albert Bandura'nın öğrenmeye yönelik geliştirdiği yaklaşım sosyal-davranışçılıktır. Bilişsel öğrenme kuramı ve analitik davranışçı kuram birleştirilerek sosyal öğrenme kuramı ortaya çıkmıştır (Yeşilyaprak, 2006: 220). Kurama göre öz yeterlik inancı, bireyin yaptığı seçimlerin ve gerçekleştirdiği çabanın, zorluklarla mücadele azim ve kararlılığının kaygı ve huzur derecesini etkilediği görüşü ortaya konmuştur (Usher ve Pajares, 2008: 751). Schunk'a göre sosyal öğrenme kuramı, öğrenmeyi “davranıştaki değişimler veya deneyimler yoluyla ortaya çıkan davranışsal potansiyel” olarak tanımlamaktadır (Sakız, 2014: 2).

Sosyal öğrenme kuramında bireyin kendi düşüncelerini eleştirebilir olması, yaptıklarının ve yapmadıklarının farkına vararak yaşaması açısından çok önemlidir. Çünkü öğrenme sürecinin ana unsuru bireyin yapacağı çalışmayı değerlendirebilmesidir. Bu durum öz yeterlik kavramıyla açıklanmıştır (Yeşilyaprak, 2002: 209). Öz yeterlik, sosyal öğrenme kuramının temel kavramıdır. Bireyin kendinin farkında olması durumudur. Bireyin sergilemesi gereken performans için kendi kapasitesini karşılaştırarak duruma göre harekete geçmelidir. Bu bağlamda öz yeterlik, bireyin karşılaşmış olduğu zorluklarla nasıl başa çıkabileceğine yönelik inancıdır (Yeşilyaprak, 2006: 229).

Öz yeterlik inancı, bireyin aktivite seçimini, harcanması gereken çabanın seviyesini ve başarı düzeyini etkilemektedir. Öz yeterlik inancı düşük olan sporcular öz yeterlik inancı yüksek olan sporculara göre takıma uyum sağlama konusunda zorluk yaşamaktadır. Bu bağlamda öz yeterlik inancı düşük sporcular öz yeterlik inancı yüksek sporculara göre daha düşük başarı göstermektedir (Aydın, 2018: 46).

\subsubsection{Hakem Öz Yeterliği}

Hakem öz yeterliği, Feltz (2008) tarafından Bandura'nın ortaya koyduğu öz yeterlik teorisinden yola çıkılarak hakemlik mesleği bağlamında kavramsallaştırılmıştır. Hakem öz yeterliği (referee self-efficacy), hakemlerin yaptıkları işte başarılı performans kapasitesine sahip olmalarına ilişkin inanç şeklinde ifade edilmiştir (aktaran Karaçam ve Pulur, 2019: 117). Hakem öz yeterliğine ilişkin ön kavramsal model, Guillén ve Feltz (2011: 2) tarafindan oluşturulmuştur. Buna yönelik aşağıda yer alan Tablo 1'de hakem öz yeterliğine ilişkin model belirtilmiştir.

Tablo 1. Hakem Öz Yeterlik Modeli

\begin{tabular}{|c|c|c|}
\hline Öz Yeterlik Kaynakları & Öz Yeterlik Boyutları & Çıktılar \\
\hline $\begin{array}{l}\text { Ustalık Deneyimi } \\
\text { "Hakem olarak deneyim, geçmiş performans, } \\
\text { hocalık deneyimi, kural bilgisi" }\end{array}$ & \multirow[b]{2}{*}{$\begin{array}{l}\text { "Fiziksel } \\
\text { yeterlik Oyun } \\
\text { bilgisi }\end{array}$} & \multirow{2}{*}{$\begin{array}{l}\text { "Hakem davranışı } \\
\text { Hakem } \\
\text { memnuniyeti } \\
\text { Hakem performansı } \\
\text { Hakem stresi }\end{array}$} \\
\hline $\begin{array}{l}\text { Diğer Önemli Kaynaklar } \\
\text { "Değerlendiricilerin varlığı ve geri dönütü, } \\
\text { hakem arkadaşlarının, oyuncu, antrenör vb. }\end{array}$ & & \\
\hline
\end{tabular}




\begin{tabular}{|c|c|c|}
\hline geri dönütüu” & \multirow{3}{*}{$\begin{array}{l}\text { Karar verme } \\
\text { becerileri Psikolojik } \\
\text { beceriler Stratejik } \\
\text { beceriler } \\
\text { Iletişim ve Oyun kontrolü", }\end{array}$} & \multirow{3}{*}{$\begin{array}{l}\text { Antrenör davranışı } \\
\text { Sporcu davranışı } \\
\text { Sporcuların } \\
\text { kurallara uyması", }\end{array}$} \\
\hline $\begin{array}{l}\text { Fiziksel Zihinsel Hazırlık } \\
\text { "Amaç belirleme, usınma, fiziksel kondisyon" }\end{array}$ & & \\
\hline $\begin{array}{l}\text { Paydaşların Nitelikleri } \\
\text { "Nitelikli maça nitelikli partnerle } \\
\text { görevlendirilme, hava şartlarının uygunluğu, } \\
\text { sahava asinalık" }\end{array}$ & & \\
\hline
\end{tabular}

Kaynak: (Guillén ve Feltz, 2011:2)

Öz yeterliğe ilişkin alan yazını incelendiğinde eğitim bilimleri alanında özellikle öğretmen örnekleminde ele alınan çalışmalara sıklıkla rastlanmaktadır. Spor bilimleri alanında antrenörler ve sporculara yönelik oldukça araştırma yapılmasına rağmen yazında hakemliğin öz yeterlik kavramı ile ilişkisinin yeterince araştırılmadığ 1 görülmektedir.

Staples vd. (1999: 760) yüksek öz yeterlik inancının örgüte bağlılık, iş başarısı ve iş tatmini düzeylerini arttırdığına vurgu yapmaktadır. Yüksek öz yeterliğe sahip hakemlerin mesleğe daha bağlı, performanslarının daha etkili, kararlarının daha doğru olması bakımından yönetici ve yetkililerden daha fazla sayg1 gördükleri belirtilmektedir (Guillén ve Feltz, 2011: 2).

Ceylan vd. (2017: 282) farklı klasmanlarda görev yapan futbol hakem ve yardımcı hakemlerinin sargınlık ve öz yeterlik düzeylerini incelemişlerdir. Karadeniz Bölgesi’nde farklı klasmanlarda görev alan 326 hakem ve yardımcı hakem çalışmaya katılım sağlamıştır. Hakemlerin klasman düzeyleri, hakemlik yapma süresi, eğitim düzeyleri ve görev yaptıkları il bakımından farklılıklar incelenmiştir. Çalışmada bölge, yaş ve tecrübeye göre farklılıklar tespit etmiştir. Sargınlık ve öz yeterlik düzeylerinin futbol hakemliğindeki önemini vurgulamıştır.

Koçak vd. (2017: 129) üniversite spor federasyonu futbol 1. Ligi müsabakalarına katılım gösteren öğrencilere ilişkin psikolojik sağlamlık ve öz yeterlik düzeylerinin belirlenmesine yönelik yapmış oldukları çalışmanın sonucunda öğrencilerin psikolojik sağlamlık düzeylerinin orta düzeyde, öz yeterliklerinin yüksek düzeyde olduğunu tespit etmiştir.

Eskiyecek vd. (2018: 72) yüzme hakemlerinin genel öz yeterlik inançlarını incelemiştir. 212 yüzme hakeminin katılım sağladığı çalışmada hakemlerin öz yeterlik inançları yaş, cinsiyet, eğitim düzeyi, klasman, hakemliği seçme nedeni, hakemlik yapma süresi, hakemlik yapma memnuniyeti değişkenlerine göre anlamlı farklılıklar göstermiştir.

Yıldırım ve Atilla (2020: 59) öğrencilerde öz yeterliğin bilinçli farkındalık ve benlik saygısına etkisini incelemiştir. 124 öğrencinin katılım sağlamıştır. Çalışmanın sonucunda öz yeterliğin bilinçli farkındalık ve benlik saygısı üzerinde anlamlı bir etkisinin olduğunu belirtmiştir.

Bayram vd. (2020: 24) hakemlerde öz yeterlik, örgütsel sessizlik ve yaşam doyumu arasındaki ilişkiyi incelemiştir. Farklı branşlarda görev yapan 250 hakemin katılım sağladığı çalışmada öz yeterliğin örgütsel sessizlik ve yaşam doyumu değişkenlerine anlamlı bir etkisinin olduğunu belirlemiştir.

\subsection{Zihinsel Dayanıklılık}

Dayanıklılık, yapılan egzersizde kas yorgunluğu olmadan veya kas yorgunluğu olmasına rağmen antrenmana devam etme özelliğidir ve performans faktörleri içinde önemli bir yere sahiptir (Akıl, 2007: 2). Alan yazınında zihinsel dayanıklılık, psikolojik sağlamlık, mental dayanıklılık ve psikolojik dayanıklılık benzer kavramlar olarak kullanılmıştır. Spor 
psikolojisinde sıklıkla kullanılan bir kavram olan zihinsel dayanıklılığa ilişskin yazında çeşitli tanımlamalar yapılmıştır. Spor ve egzersiz psikolojisinin ilk zamanlarında zihinsel dayanıklılık, doruk performans ile ilişkilendirilerek "yılmazlık" ve "kararlılık" kavramlarının yerine kullanılmıştır (Moran, 2004; aktaran Akman, 2019: 5).

Zihinsel dayanıklılık, başarılı olamama, sorumluluk artışı, çatışma, terslik gibi olumsuz durumlarda bireyin kendini toparlaması için kullanılan ve geliştirilebilen psikolojik kapasite olarak nitelendirilmiştir (Luthans, 2002). Graham, Hanton ve Connaughton (2002: 205), zihinsel dayanıklılık kavramının uygulamalı spor psikolojisinde sıklıkla kullanılmasına rağmen az anlaşılan kavramlardan biri olarak konunun önemini belirtmektedir.

Connaughton vd., (2008: 83) zihinsel dayanıklılığın gelişiminde birçok unsurun bulunduğunu belirtmektedir. $\mathrm{Bu}$ unsurlar; motivasyonal iklim, çevresel iklim (akrabalar, akranlar, takım arkadaşları, antrenörler, spor psikologları), spor içi ve spor dışı deneyimler, psikolojik yetenekler ve stratejiler, başarıya ulaşmak için istek ve içselleşmiş güdüler olarak vurgulanmıştır. Clough vd., (2002) çalışmasında zihinsel dayanıklılığın dört temel bileşenden meydana geldiğini ifade etmiştir. Buna ilişkin model Tablo 2'de açıklanmaktadır.

Tablo 2. Zihinsel Dayanıklılı 4C Modeli

\begin{tabular}{|c|c|c|}
\hline Bileşen & Tanımlama & Gelişim Stratejisi Örneği \\
\hline $\begin{array}{l}\text { Kontrol } \\
\text { (Control) }\end{array}$ & $\begin{array}{l}\text { "Birden fazla durumu idare edebilme, } \\
\text { başka bir dış etkinin kontrolü altına } \\
\text { girmeden performans sürdürme becerisi" }\end{array}$ & $\begin{array}{l}\text { "Antrenmanlarda dikkat } \\
\text { dağıtabilecek unsurların } \\
\text { eklenmesi" }\end{array}$ \\
\hline $\begin{array}{l}\text { Meydan Okuma } \\
\text { (Challenge) }\end{array}$ & $\begin{array}{l}\text { "Olası tehditleri kişisel gelişim firsatı } \\
\text { olarak görebilme ve sürekli gelişen } \\
\text { çevresel değişimi kavrayabilme" }\end{array}$ & $\begin{array}{l}\text { "Değişen durumlara yönelik } \\
\text { adaptasyonun arttırlması" }\end{array}$ \\
\hline $\begin{array}{c}\text { Kararlılık } \\
\text { (Commitment) }\end{array}$ & $\begin{array}{l}\text { "Zorluklara rağmen belirlenen hedefe } \\
\text { ulaşmaya yönelik çaba ve amaç göstermek ile } \\
\text { yakından iliş̧kili olma" }\end{array}$ & $\begin{array}{l}\text { "Hedef belirleme ve } \\
\text { hedeflere ulaşabilme" }\end{array}$ \\
\hline $\begin{array}{c}\text { Özgüven } \\
\text { (Confidence) }\end{array}$ & $\begin{array}{l}\text { "Başarısızlıklara rağmen kendine olan } \\
\text { inancı sürdürme ve rakipler karşısında } \\
\text { sinmeme becerisi" }\end{array}$ & $\begin{array}{l}\text { "Zor durumlarla yüzleşme ve } \\
\text { başa çıkabilme" }\end{array}$ \\
\hline
\end{tabular}

Kaynak: (Clough vd., 2002; aktaran Bayköse ve Keskin, 2018: 45).

\subsubsection{Hakemlikte Zihinsel Dayanıklılık}

Hakemlerin yoğun baskı altında hızlı ve doğru yönde karar vermesi beklenirken, bu kararlarla oyunun sonucuna da önemli derecede etki edebilmektedirler. Zihinsel dayanıklılık, bireyin hedefe ulaşmak adına zor durumlarda yeteneklerine olan inancı ve rakiplerden daha iyi olduğunu düşünme durumudur (Sheard, 2013; aktaran Altıntaş, 2015: 11). Bu kapsamda özellikle futbolda zihinsel dayanıklılık önemli bir boyut kazanmıştır. Zihinsel dayanıklılık yazınında bireysel sporcular ve takım sporcularına yönelik pek çok araştırma yapılmasına rağmen hakem örnekleminde az sayıda çalışmaya rastlanmıştır.

Slack vd. (2013: 302) İngiltere Premier Lig'de görev yapan hakemlerin zihinsel dayanıklılık özelliklerini inceleyen çalışmada çeşitli faktörleri tanımlamışlardır. Bu faktörler; baskı ile başa çıkma, esneklik, sağlam öz inanç, sert tutum, başarı çabası, yüksek iş ahlakı ve oyun zekâsı şeklinde temalandırılmıştır. 
Slack vd., (2014: 1) İngiltere Premier Lig'de görev alan futbol hakemlerinin zihinsel dayanıklılığın gerektirdiği davranışlarını ve bilişlerini belirlemeye yönelik yarı yapılandırılmış bir mülakat gerçekleştirmiştir. İçerik analizi yoluyla 70 durum beş üst düzey temaya dönüştürülmüştür. $\mathrm{Bu}$ temalar; maç öncesi durumlar, maç sırası durumlar, maç sonrası durumlar, genel hakemlik durumları ve genel yaşam durumları olarak ele alınmıştır.

Samuel (2015: 6) elit futbol hakemlerinin taleplerine yönelik kapsamlı bir psikolojik hazırlık çerçevesi oluşturmuştur. İyi bir performans göstermeleri için hakemlerin doğru konum alarak doğru kararlar vermeli, hatalı bir karar sonrası dikkatini ve öz yeterliğini korumalı, etkili oyun yönetimi becerileri ile oyunculara saygı duymalı, ortak bir zihinsel model oluşturup ekibi ile etkili iletişim kurması gerektiğine değinmiştir.

Miçooğulları vd., (2017: 1970) futbol hakemlerinin arasındaki zihinsel dayanıklılık düzeylerini karşılaştırdığı çalışmada hakemlerin kıdem yılı ile zihinsel dayanıklılıkları arasında anlamlı farklılıklar ortaya çıkmıştır. 14 yıl ve üzeri hakem tecrübesi bulunan hakemlerin 0-5 ve 6-10 yılları arasında hakemlik tecrübesine sahip olan hakemlere göre zihinsel olarak daha dayanıklı olduklarını saptamıştır.

Ekmekçi ve Miçooğulları (2017: 892) elit ve klasman hakemlerinden oluşan 88 futbol hakemi örneklemindeki çalışmanın sonucunda hakemlerin klasmanları ve spor deneyim yaşları arasında farklılıklara ulaşmışlardır. Elit hakemlerin klasman hakemlerine göre zihinsel dayanıklılıkları daha üst seviyede çıkmıştır.

Yıldız ve Y1lmaz (2017: 848) sporcularda zihinsel dayanıklılık ve öz yeterlik düzeyleri arasındaki ilişkiyi inceleyen çalışmada zihinsel dayanıklılık ile öz yeterlik arasında pozitif yönlü anlamlı ilişki olduğunu saptamış, yaş değişkeni ve eğitim düzeyi değişkeni bakımından zihinsel dayanıklılık düzeylerinin farklılaştığına değinmiştir.

\section{3. Örgüte Bağlılık}

Türkçe literatürde çoğunlukla örgütsel bağlllık olarak karşımıza çıkan organizational commitment kavramı, kavramın gerçek anlamı gereğince bu çalışmada tercihen örgüte bağlılık olarak ele alınmıştır. Zira kavrama adını veren bağlılığın, örgütsel bir durumu değil bireyin örgüte yönelik bağlılığını ifade ettiği düşünülmektedir. Bağlılık, insanın ihtiyaç duyduğu en temel duygu durumlarından biridir. Türk Dil Kurumu (2020) tanımına göre bağlllık "birine karşı sevgi, sayg ile yakınlık duyma ve gösterme, sadakat” şeklinde açıklanmıştır.

Özdaşlı vd., (2009: 232) örgüte bağlılığ1, "bir iş görenin, örgütün amaçlarına ve değerlerine kuvvetle inanması, örgütün faydasına ilişkin beklenilenin ötesinde çaba sarf etmeye istekli olmasl ve örgütün üyesi olarak kalmayı kuvvetle istemesi" şeklinde belirtmektedir. Hedeflere ulaşma aşamasında bireyin, sürekli görev alma isteğinde bulunması, verilen emirleri eksiksiz yerine getirme arzusu ve bağlı olduğu örgütten ayrılmayı düşünmemesi durumudur. Bu bağlamda örgüte bağlılık; çalışanların örgütte kalmak istemeleri, örgüte yönelik sadık tutumları ve örgütün başarısı adına ilgi göstermeleri gibi durumları ifade etmektedir (Mete vd., 2015: 143).

Örgütlerin devamlılığının sağlanması için tüm çalışanların uyum ve işbirliği içinde görev ve sorumluluklarını yerine getirmeleri gerekmektedir. Grup içerisinde bunların meydana gelmesi için uygun ortam sağlanmalıdır. Bu bağlamda çalışanlardan yüksek iş verimi beklemek çalışanların üretim için şartlanmalarıyla oluşmaktadır. Dolayısıyla bu durum bağlılık duygusunun gelişimiyle oluşur (Sığr1, 2007: 262). 
İş görenle örgütün arasındaki bağlılık; duygusal bağl1lık, devam bağl1lı̆ğ ve normatif bağl1lık olarak üç ögeye ayrılmaktadır. Duygusal bağlılığı olan çalışan örgütün amaç ve hedeflerini gerçekleştirmeye yönelik yoğun çaba sarf eder. Örgüte karşı olumlu duygular hisseden çalışan örgütte çalışmayı sürdürür ve örgütün bir üyesi olmaktan gurur duyar (Meyer ve Allen, 1991: 67). Devam bağlılığının temelini Becker'in yan bahis yaklaşımı oluşturmaktadır. Devam bağlılığı, bireyin örgütte çalıştığ 1 süre zarfinda gösterdiği çabayla elde ettiği para, statü vb. kazanımları örgütten ayrılmasıyla kaybedeceği düşüncesiyle gelişen bağlılık türüdür. Bir diğer ifadeyle bireyin örgütte kalmaya duyduğu ihtiyacı tanımlamaktadır (Günce, 2013: 28). Normatif bağlılık, örgütün çalışanına yaptığı yatırımlar ve harcamalar sonrasında çalışanın örgüte karşı kendisini borçlu hissetmesini nitelemektedir. Bu durum çalışanı örgütünde kalmaya zorlamaktadır (Meyer ve Allen, 1991: 72).

Örgütsel davranış disiplininde örgüte bağlılık konusu araştırmacılar tarafından yoğun ilgi görmüştür. Günümüzde de bu ilgi artarak devam etmektedir. Hoş ve Oksay (2015) örgütsel bağlılık ile iş tatmini ilişsisini hemşire örnekleminde incelemiştir. İçsel tatmin ve dişsal tatmin boyutlarının örgütsel bağlılık ile pozitif yönlü anlamlı bir ilişkisinin olduğunu tespit etmiştir.

Atilla Gök (2016: 104) örgütsel bağlılığın örgütsel sessizlik üzerindeki etkisini incelemiştir. Sonuç olarak devam bağlılığının ilişkisel sessizliği ve kabullenici sessizliği pozitif yönde kuvvetli bir şekilde etkilediğini tespit etmiştir. Duygusal bağlılık ve devam bağlılığının

kabullenici sessizliği negatif yönde kuvvetli bir şekilde etkilediğini vurgulamıştır. Normatif bağlılığın ise savunmacı sessizlik üzerinde anlamlı bir etkisinin bulunmadığını belirtmiştir.

Köybaşı ve Dönmez (2017: 266) öz yeterlik, örgüte bağlılık ve girişimcilik algı düzeylerini incelemiştir. Okul yöneticilerinin öz yeterlik algıları ile kıdem değişkeni arasında istatistik olarak anlamlı bir fark tespit edilmemiştir. Okul yöneticilerinin okul türüne göre öz yeterlik inanc1, örgüte bağlılık ve girişimcilik algıları arasında istatistiksel açıdan anlamlı bir fark saptanmamıştır.

Yıldız ve Atilla (2019: 39) otel çalışanları örnekleminde yaptıkları çalışmada yönelik örgütsel adalet algısının örgütsel bağlılık düzeyine etkisini incelemiştir. Çalışmada örgütsel adalet algısının örgüte bağlılık düzeyini etkilediği ortaya konmuştur.

Yıldız (2011: 216) spor okullarında antrenörlerin içsel pazarlama, iş tatmini ve örgütsel bağlılık değişkenleri arasında anlamlı ve pozitif bir ilişkinin varlığını tespit etmiştir. İş tatmininin içsel pazarlama ve örgütsel bağlılık arasında kısmi aracılık etkisinin olduğunu vurgulamıştır.

\section{ARAŞTIRMANIN METODOLOJISI}

\subsection{Araştırmanın Amacı ve Modeli}

Araştırmanın amacı, 2018-2019 Futbol Sezonu Türkiye Futbol Federasyonu 5. Bölge'de Antalya, Isparta ve Burdur illerinde görev yapan faal futbol hakemlerinin zihinsel dayanıklılık ve örgüte bağlılık ilişkisinde öz yeterliğin aracılık rolünü incelemektir. $\mathrm{Bu}$ bağlamda araştırmanın problem cümlesi ise "futbol hakemlerinin zihinsel dayanıklılık ve örgüte bağlılık ilişkisinde öz yeterliğin aracılık etkisi var mıdır?” şeklindedir. Literatürde doğrudan zihinsel dayanıklılık, örgüte bağlılık ve öz yeterlik değişkenlerini inceleyen herhangi bir çalışmaya araştırma dâhilinde rastlanmamıştır. $\mathrm{Bu}$ bağlamda araştırmanın yazına önemli bir katkı sunacağ1 düşünülmektedir.

\subsection{Araştırmanın Evreni ve Örneklemi}


2018-2019 Futbol Sezonu Türkiye Futbol Federasyonu 5. Bölge'de bulunan Antalya, Isparta ve Burdur illerinde görev alan faal futbol hakemleri araştırmanın evrenini oluşturmaktadır. Araştırmanın örneklemini ise TFF 5. Bölge'de yer alan Antalya, Isparta ve Burdur illerinde il ve aday hakem statüsünde bulunan faal futbol hakemleri oluşturmaktadır. Araştırmada kolayda örneklem tekniği uygulanmıştır. Araştırma evreninde yer alan yaklaşık 450 (N) futbol hakemine ilişkin örneklem hesaplamasında Yamane (2001: 116) tarafından geliştirilen yöntemden faydalanılmıştır. Formülün uygulanması sonucunda örneklem büyüklüğü (n)=207 olarak bulunmuştur. Dolayısıyla evreni temsil etmek için 207 'den daha fazla kişiye ulaşmak yeterli olacaktır. Bu bakımdan çalışmaya ilişkin ulaştığımız 235 kişilik örneklem sayısı, evreni temsil etmesi bakımından yeterlidir.

\subsection{Veri Toplama Aracı}

Araştırmada veri toplama aracı olarak anket tekniğinden faydalanılmıştır. 2019 yılı TFF EPAK Nisan ayı eğitiminde hakemlerle yüz yüze anket çalışması yapılmıştır. Anketlerden eksik ve hatalı doldurulduğu anlaşılan 14 anket araştırmaya dâhil edilmemiştir. $\mathrm{Bu}$ bağlamda araştırmanın analizleri hatasız kabul edilen 235 anketten oluşmaktadır. Ölçek ifadelerinin değerlendirilmesinde "Kesinlikle Katılmıyorum (1)”, "Katılmıyorum (2)”, "Ne katıllyorum, ne de katılmıyorum (3)”, “Katıllyorum (4)” ve "Kesinlikle Katıllyorum (5)” ifadelerinden oluşan "Likert” tipi beşli dereceleme ölçeği uygulanmıştır.

Kişisel Bilgi Formu: Hakemlerin demografik ve sosyal özelliklerini belirlemek için 11 soru bulunmaktadır. Anketin ilk bölümünde araştırmaya katılan hakemlerin cinsiyet, medeni durum, yaş, meslek, öğrenim durumu, yabancı dil bilgisi, futbol oynama durumu, ailede hakem olma durumu, hakemlik yapma yılı, klasman durumu, klasman yükselme ve düşme durumu gibi hakemlerin kişisel özelliklerini belirlemeye yönelik sorular yer almaktadır. Hakemlerin kişisel özelliklerine yönelik açık uçlu ve kapalı uçlu sorunlar bulunmaktadır. Ankette yer alan ölçeklere ilişkin bilgilere aşağıda yer verilmiştir.

Sporda Zihinsel Dayanıklılı Envanteri: Anketin ikinci bölümünde hakemlerin zihinsel dayanıklılıklarını belirlemeye yönelik 3 alt boyutlu (güven, kontrol, devamlılık) 14 ifadeli "Sporda Zihinsel Dayaniklllı Envanteri (Sport Mental Toughness Questionnaire)" kullanılmıştır. Sheard vd., (2009) tarafindan oluşturulan Sporda Zihinsel Dayanıklılık Envanteri'nin 4'lü Likert yapıdaki Cronbach Alfa değerleri güven boyutunda (0.72), devamlılık boyutunda (0.71) ve kontrol boyutunda (0.66) olarak bulunmuştur. Altıntaş ve Koruç (2016) tarafından ölçeğin Türkçe uyarlama çalışması gerçekleştirilmiştir. Ölçeğin alt boyutlarının güvenilirlik değerleri güven boyutu için (0.84), kontrol boyutu için (0.79), devamlılık boyutu için (0.51) şeklindedir. Bu sonuçlar doğrultusunda ölçeğin güvenilir bir ölçek olduğu sonucuna varılmıştır (Altıntaş, 2016: 162).

Örgütsel Bağlılık Ölçeği: Anketin üçüncü bölümünde hakemlerin futbol federasyonuna bağlılıklarını ölçmek için Allen ve Meyer'in 3 alt boyut (duygusal bağlılık, devam bağlılığı, normatif bağlılık) 18 ifadeli "Örgütsel Bă̆lllık Ölçeği (Organizational Commitment Scale)" kullanılmıştır. Wasti (2000) tarafından Türkçe uyarlaması yapılan ölçeğin Cronbach Alfa katsayıları kamu çalışanları örnekleminde duygusal bağlılık alt boyutu için (0.79), devam bağl1lığ1 alt boyutu için (0.58), normatif bağlllık alt boyutu için (0.75)'dir. Özel sektör çalışanları örnekleminde ise güvenilirlik değerleri duygusal bağlılık alt boyutu için (0.78), devam bağlılığı alt boyutu için (0.60), normatif bağlılık alt boyutu için (0.80) şeklinde hesaplanmıştır (Wasti, 2000: 404).

Hakem Öz Yeterlik Ölçeği: Guillen ve Feltz (2011) tarafından temeli hazırlanan, Myers ve arkadaşları (2012) tarafından da geliştirilen “Hakem Öz Yeterlik Ölçeği (Referee Self-Efficacy 
Scale) ” Karaçam ve Pulur (2017) tarafindan Türkçe uyarlaması yapılmıştır ve ölçeğe sonradan fiziksel yeterlik faktörü de eklenmiştir. Ölçeğin güvenilirlik katsayıları fiziksel yeterlik alt boyutu için (0.88), oyun bilgisi alt boyutu için ( 0.71$)$, karar verme alt boyutu için $(0.85)$, bask1 alt boyutu için (0.88), iletişim alt boyutu için (0.81) ve ölçeğin tümü için (0.90) olarak belirtilmiştir.

\subsection{Araştırma Modeli ve Hipotezleri}

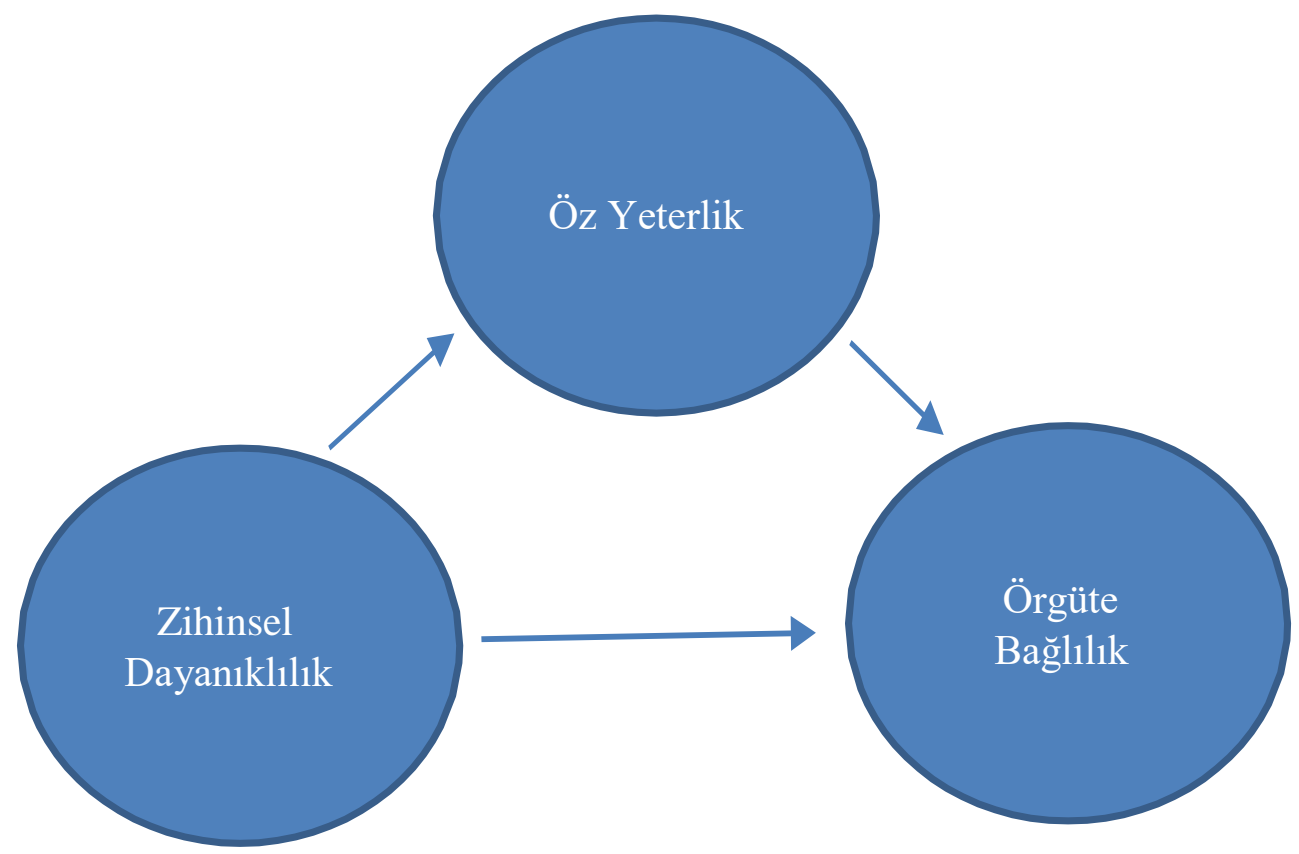

Şekil 1. Araştırma Modeli

Örgütsel davranış çalışmalarında aracılık rolünü inceleyen birçok çalışma mevcuttur (Taylor vd., 2007; Akçakanat vd., 2019; Dinç vd., 2019). Aracı değişken ilişkisinde üç koşulun sağlanması gerekmektedir (Baron ve Kenny, 1986: 1776). Birinci koşulda, bağımsız değişken aracı değişkende bir değişime sebep olmalıdır. İkinci koşulda, aracı değişken bağımlı değişkende değişime sebep olmalıdır. Üçüncü koşulda, aracı değişken ve bağımsız değişkenler birlikte analiz edilmesi durumunda bağımsız değişkenin bağımlı değişken üzerindeki etkisi ya azalmalı ya da tamamen ortadan kalkmalıdır (Yürür ve Keser, 2011: 178-179). Üçüncü koşulda bağımsız değişkenin etkisi tamamen ortadan kalkıyorsa veya bağımsız değişken ile bağımlı değişken arasında bir ilişki (etki) yoksa bu "tam aracılık (full mediation)" ilişkisi olarak tanımlanmaktadır. Eğer bağımsız değişken ile bağımlı değişken arasındaki ilişki (etki) devam ediyorsa bu durum başka aracı değişkenlerin varlığına işarettir. Bu durumda değişkenin "kısmi aracılık (partial mediation)" etkisinden söz etmek mümkündür (Baron ve Kenny, 1986: 1777). Araştırma modeline ilişkin oluşturulan hipotezler aşağıda sırasıyla belirtilmiştir:

Hipotez 1: Zihinsel dayanıklılığın hakem öz yeterliği üzerinde pozitif bir etkisi vardır.

Hipotez 2: Zihinsel dayanıklılığın örgüte bağlılık üzerinde pozitif bir etkisi vardır.

Hipotez 3: Hakem öz yeterliğinin örgüte bağlılık üzerinde pozitif bir etkisi vardır. 
Hipotez 4: Zihinsel dayanıklılığın örgüte bağlılık üzerindeki etkisinde hakem öz yeterliğinin aracılık rolü vardır.

\section{BULGULAR}

\subsection{Demografik ve Sosyal Özeliklere İlişkin Bulgular}

Tablo 3. Demografik ve Sosyal Özelliklere İlișkin Bulgular

\begin{tabular}{|c|c|c|c|c|c|}
\hline Demografik ve Sosyal Özellikler & $\mathbf{N}$ & $\%$ & Demografik ve Sosyal Özellikler & $\mathbf{N}$ & $\%$ \\
\hline \multicolumn{3}{|l|}{ Cinsiyet } & \multicolumn{3}{|l|}{ Meslek } \\
\hline Erkek & 210 & 89.4 & Öğrenci & 149 & 63.4 \\
\hline Kadın & 25 & 10.6 & Özel Sektör & 33 & 14 \\
\hline \multicolumn{3}{|l|}{ Medeni Durum } & Kamu Sektörü & 32 & 13.6 \\
\hline Evli & 33 & 14 & Çalışmıyor & 16 & 6.8 \\
\hline Bekar & 202 & 86 & Diğer & 5 & 2.1 \\
\hline \multicolumn{3}{|l|}{ Yaş } & \multicolumn{3}{|l|}{ Futbol Oynama Durumu } \\
\hline 18 yaş ve altı & 34 & 14.5 & Amatör lisansli & 140 & 59.6 \\
\hline $19-24$ yaş & 133 & 56.2 & Profesyonel & 6 & 2.6 \\
\hline $25-30$ yaş & 40 & 17 & Hayır & 89 & 37.9 \\
\hline 31 yaş ve üzeri & 28 & 11.5 & \multicolumn{3}{|l|}{ Ailede Hakem Olma Durumu } \\
\hline \multicolumn{3}{|l|}{ Yaşanılan Yer } & Evet, var & 38 & 16.2 \\
\hline Büyükşehir & 69 & 29.4 & Hayır. yok & 197 & 83.8 \\
\hline İl & 114 & 48.5 & \multicolumn{3}{|l|}{ Hakemlik Yılı } \\
\hline İlçe & 52 & 22.1 & 1 y1l ve alt1 & 110 & 46.8 \\
\hline \multicolumn{3}{|l|}{ Eğitim Durumu } & $2-6$ & 84 & 35.7 \\
\hline Lise & 70 & 29.8 & $7-11$ & 24 & 10.2 \\
\hline Ön lisans & 46 & 19.6 & 12 y1l ve üzeri & 17 & 7.2 \\
\hline Lisans & 113 & 48.1 & \multicolumn{3}{|l|}{ Klasman } \\
\hline Lisansüstü & 6 & 2.6 & İl & 129 & 54.9 \\
\hline \multicolumn{3}{|l|}{ Yabancı Dil Bilgisi } & Aday & 106 & 45.1 \\
\hline İngilizce (Başlangıç) & 104 & 44.3 & \multicolumn{3}{|c|}{ Klasman Yükselme/Düşme Durumu } \\
\hline İngilizce (Orta) & 100 & 42.6 & Yükseldim & 112 & 47.7 \\
\hline İngilizce (İyi) & 31 & 13.2 & Her ikisini de & 17 & 7.2 \\
\hline Toplam & 235 & 100 & Hiçbiri & 106 & 45.1 \\
\hline
\end{tabular}

Futbol hakemlerinin cinsiyet dağılımına göre \%89.4'ünün erkek, \%10.6'sının ise kadın olduğu tespit edilmiştir. Medeni duruma göre dağılımda \%14'ünün evli, \%86'sının evli olmadığ görülmektedir. Futbol hakemlerinin yaş dağılımına göre dağılımda \%14.5'inin 18 yaş ve altında, \%56.2'sinin 19-24 yaş aralığında, \%17'si 25-30 yaş aralığında, \%11.5'i 31 yaş ve üzerindedir. Yaşanılan yer durumuna göre dağılımda \%29.4'ünün büyükşehir, \%48.5'inin il, \%22.1'inin ise ilçede yaşamını sürdürdüğü görülmektedir. Eğitim durumuna göre dağılımda 
\%29.8'inin lise, \%19.6'sının ön lisans, \%48.1'i lisans ve \%2.6's1 ise lisansüstü eğitim görmüştür. Yabancı dil (İngilizce) bilgisi düzeyine göre dağılımda \%43.8'inin başlangıç, $\% 43$ 'ünün orta ve \%13.2'sinin iyi düzeyde yabancı dil bilgisine sahip olduğu görülmektedir. Meslek durumuna göre dağılımda \%63'ünün öğrenci, \%14'ünün özel sektör, \%14'ünün kamu sektörü, \%6.8'inin çalışmıyor olduğu, \%2.1'inin diğer sektörlerde çalıştığı görülmektedir. Futbol oynama durumuna göre dağılımda \%59.6'sının amatör lisanslı, \%2.6'sının profesyonel lisanslı futbol oynadığı, \%37.9'unun da futbol oynamadığı görülmektedir. Ailede hakem olma durumuna göre dağılımda \%16.2'sinin ailede hakem olduğu, \%83.8'inin ise ailede hakem olmadığ 1 görülmektedir. Hakemlik yılına göre dağılımda \%46.8'inin 1 yıl ve altı, \%35.7'sinin 2-6 yıl aralığında, \%10.2'sinin 7-11 yıl aralığında, \%7.2'sinin ise 12 yıl ve üzeri tecrübesi bulunmaktadır. Klasman durumuna göre dağılımda \%54.9'unun il hakemi, \%45.1'inin ise aday hakem statüsünde görev yaptığı görülmektedir. Klasman yükselme-düşme durumuna göre dağılımda ise hakemlerin \%47.7'sinin klasman yükseldiği, \%45.1'inin herhangi bir yükselme ve düşme yaşamadığ 1 , \% 7.2'sinin klasmanda yükselme ve düşme yaşadığ 1 görülmektedir.

\subsection{Normallik Analizine İlişkin Bulgular}

Bir verinin normal dağılıma sahip olup olmadığı birçok farklı yöntemle tespit edilmektedir. Bu bağlamda ilk olarak skewness (çarpıklık) ve kurtosis (basıklık) değerlerine bakılabilir. Bu değerlerin $(-2 /+2)$ aralığında olması verilerin normal dağılıma sahip olduğunu gösterebilir. Araştırmada yer alan gözlem sayısı 29 üzerinde olduğu için normallik testi kapsamında Kolmogorov-Smirnov testi kullanılması önerilmektedir (Karaatlı, 2018: 10). Örneklem büyüklüğü 200'den fazla olan veri setleri normal dağılım özelliği göstermemelerine rağmen normallik varsayımı gerektiren analizlerde (Anova vb.) genellikle daha güvenilir sonuçlar verebilmektedir. $\mathrm{Bu}$ bakımdan normallik varsayımını aşırı şekilde ihlal etmeyen geniş örnekleme sahip verilerin dönüştürme işlemine tabi tutulmaksızın özgün halleri ile kullanılmasında herhangi bir sakınca olmadığı belirtilmektedir (Gürbüz ve Şahin, 2017: 215).

Tablo 4. Normallik Testi Sonuçları

\begin{tabular}{|c|c|c|c|c|c|}
\hline \multirow{2}{*}{ Ölçekler } & \multirow{2}{*}{ Çarpıklık } & \multirow{2}{*}{ Basıklık } & \multicolumn{3}{|c|}{ Kolmogorov-Smirnov } \\
\cline { 4 - 6 } & & & İstatistik & Df & Sig. (p) \\
\hline SZDE & .614 & .944 & .102 & 235 & .000 \\
\hline ÖB & -.341 & .567 & .052 & 235 & .200 \\
\hline HÖYÖ & -1.821 & 5.817 & .148 & 235 & .000 \\
\hline
\end{tabular}

Tablo 4'de görüleceği üzere ölçeklere ait ifadelerin normal dağılıma sahip olup olmadığı Kline (2011) tarafından önerilen ölçekteki ifadelerin çarpıklık ve basıklık aralıklarına göre çarpıklık değeri $|3|$ 'ten, basıklık değerleri ise |10|'dan büyük olmamalıdır (Özşahin, 2017: 756). Bu sonuçlar doğrultusunda verilerin normal dağılım gösterdiği saptanmıştır. Araştırmada parametrik analizlerin kullanılmasına karar verilmiştir.

\subsection{Güvenilirlik ve Geçerliliğe İlişkin Bulgular}

Ölçeklerin güvenilirliğinin test edilmesine ilişkin en çok tercih edilen yöntemlerden biri “Cronbach Alfa Katsayısı” dır. Ölçeklerin içsel tutarlılıklarını belirlemek için yapılan analizde güvenilirlik katsayısı 0 ile 1 arasında değerler almaktadır. Bu değerlere bağlı olarak güvenilirlik düzeyleri " $0.00 \leq \alpha<0.40$ güvenilir değil, $0.40 \leq \alpha<0.60$ güvenilirliği düşük, $0.60 \leq \alpha<0.80$ güvenilir, $0.80 \leq \alpha<1.00$ ise güvenilirliği yüksektir." ş̧eklinde yorumlanmaktadır (Kayış, 2018: 405). 
Tablo 5. Güvenilirlik Testi Sonuçları

\begin{tabular}{|c|c|c|}
\hline Ölçekler & Madde Sayısı & Cronbach Alfa Değeri \\
\hline SZDE & 14 & 0.627 \\
\hline ÖB & 18 & 0.825 \\
\hline HÖYÖ & 18 & 0.948 \\
\hline
\end{tabular}

Tablo 5'te görüleceği üzere ölçeklerin güvenilirlik analizi sonuçlarına ilişkin Cronbach Alfa katsayıları incelendiğinde SZDE’nin güvenilir (0.627), ÖB'nin (0.825) ve HÖYÖ’nün de oldukça yüksek güvenilirliğe (0.948) sahip olduğu görülmektedir.

Gürbüz ve Şahin (2017: 315) faktör analizini “birbiriyle ilişkili çok sayıda maddenin bir araya getirilerek birbirleri ile tutarl daha az sayıda faktör elde etmek ve maddelerin oluşturduğu yapıların örüntüsünü keşfetmeyi amaçlayan analizlerin genel adı" olarak açıklamıştır. KaiserMeyer-Olkin (KMO) testi ise değişkenlerin oluşturduğu veri yapısının yeterli olup olmadığını göstermektedir. KMO değerinin 0.60 ve üstünde olması durumunda faktör analizi için yeterli olacağı belirtilmektedir (Gürbüz ve Şahin, 2017: 317).

Tablo 6. Sporda Zihinsel Dayanıklıık Envanteri Faktör Analizi Sonuçları

\begin{tabular}{|c|c|c|c|}
\hline İfadeler & $\begin{array}{c}\text { Faktör } \\
1\end{array}$ & $\begin{array}{c}\text { Faktör } \\
2\end{array}$ & $\begin{array}{c}\text { Faktör } \\
3\end{array}$ \\
\hline "Soğukkanlılı̆̆ımı bir an kaybetsem bile tekrar kazanabilirim" & .738 & & \\
\hline "Yeteneğim konusunda sarsılmaz bir güvene sahibimdir", & .735 & & \\
\hline $\begin{array}{l}\text { "Baskı altında iken iyi performans göstermek için yapmam gerekene } \\
\text { sahibim" }\end{array}$ & .716 & & \\
\hline "Beni diğer yarlşmacılardan ayıran niteliklere sahibim" & 696 & & \\
\hline "Potansiyel tehditleri olumlu firsatlar olarak yorumlarım" & 693 & & \\
\hline "Baskı altında, güven ve sorumlulukla kararlar alabilirim" & .689 & & \\
\hline "Kötü performans göstermekten endişelenirim" & & .767 & \\
\hline "Görevde yetersiz kalma duygusundan çok etkilenirim" & & .781 & \\
\hline $\begin{array}{l}\text { "Olaylar istediğim gibi gitmezse hayal kırıklı̆̆ına uğrar ve } \\
\text { sinirlenirim" }\end{array}$ & & .765 & \\
\hline $\begin{array}{l}\text { "Beklemediğim veya kontrol edemediğim olaylar karşısında } \\
\text { kaygılanırım" }\end{array}$ & & .780 & \\
\hline "Yapmak zorunda olduğum görevleri tamamlamakta kararlyyımdır" & & & .709 \\
\hline "Zor durumlarda vazgeçerim" & & & .430 \\
\hline "Dikkatim kolaylıkla dağılır ve konsantrasyonumu kaybederim", & & & .446 \\
\hline $\begin{array}{l}\text { "Kendime zor ve mücadeleci hedefler belirlemek konusunda sorumluluk } \\
\text { alırlm" }\end{array}$ & & & .597 \\
\hline KMO Değeri & \multicolumn{3}{|c|}{.808} \\
\hline Barlett Küresellik Değeri & \multicolumn{3}{|c|}{1118.695} \\
\hline Anlamlılık & \multicolumn{3}{|c|}{0.000} \\
\hline
\end{tabular}


Toplam Açıklanan Varyans Değeri

56.804

Tablo 6'da görüleceği üzere KMO değerinin (0.808) ve Barlett küresellik testinin anlamlı olması $(0.00<0.05)$ örneklemin faktör analizi için yeterliliğini belirtmektedir. Yapılan faktör analizi neticesinde ifadeler 3 boyutta toplanmıştır. Faktör 1: Güven boyutunu, Faktör 2: Kontrol boyutunu, Faktör 3: Devamlılık boyutunu ifade etmektedir. Ölçeğin açıklanan varyans değerinin 56,804 olduğu belirlenmiştir.

Tablo 7. Örgütse Bağlılık Ölçeği Faktör Analizi Sonuçları

\begin{tabular}{|c|c|c|c|}
\hline İfadeler & $\begin{array}{c}\text { Faktör } \\
1\end{array}$ & $\begin{array}{c}\text { Faktör } \\
2 \\
\end{array}$ & $\begin{array}{c}\text { Faktör } \\
\mathbf{3}\end{array}$ \\
\hline $\begin{array}{l}\text { "Mesleğimin geri kalan kısmını TFF'de geçirmekten çok mutluluk } \\
\text { duyarım" }\end{array}$ & .767 & & \\
\hline "TFF'nin problemlerini gerçekten kendi problemim gibi görürüm" & .799 & & \\
\hline "TFF'ye karşıl güçlü bir aidiyet hissim vardır" & .854 & & \\
\hline "TFF'ye karşı kendimi "duygusal olarak bağll” hissediyorum" & .824 & & \\
\hline "Kendimi TFF'de "ailenin bir parçası" gibi hissediyorum" & .816 & & \\
\hline "TFF'nin benim için çok özel bir anlamı vardır" & .743 & & \\
\hline $\begin{array}{l}\text { "Şu anda TFF'de kalma isteğim biraz da mecburiyetten } \\
\text { kaynaklanmaktadır" }\end{array}$ & & .530 & \\
\hline "Şu anda istesem bile işimi bırakmak benim için çok zor olurdu" & & .471 & \\
\hline "Şu anda TFF'den ayrllmaya karar versem hayatım altüst olur" & & .523 & \\
\hline $\begin{array}{l}\text { "TFF'ye kendimden bu kadar çok şey vermemiş olsaydım başka bir } \\
\text { yerde } \\
\text { çalışmayı düşünebilirdim" }\end{array}$ & & .614 & \\
\hline $\begin{array}{l}\text { "TFF'yi bıraktı̆̆ımda ortaya çılkacak birkaç olumsuzluktan biri de } \\
\text { mevcut iş olanaklarımın azlığıdır" }\end{array}$ & & 653 & \\
\hline $\begin{array}{l}\text { "Benim için daha avantajlı bile olsa şu an TFF'yi terk etmenin doğru bir } \\
\text { hareket olduğunu düşünmüyorum" }\end{array}$ & & & .772 \\
\hline "Şu an TFF'yi bıraksam suçluluk duyardım”" & & & .566 \\
\hline "TFF benim sadakatimi hak ediyor" & & & .573 \\
\hline $\begin{array}{l}\text { "TFF'yi şu an için bırakamazdım, çünkü kendimi buradakilere karşı } \\
\text { mecbur hissediyorum” }\end{array}$ & & & 642 \\
\hline "TFF'ye çok şey borçluyum" & & & .438 \\
\hline KMO Değeri & \multicolumn{3}{|c|}{.887} \\
\hline Barlett Küresellik Testi & \multicolumn{3}{|c|}{1382.638} \\
\hline Anlamlılık & \multicolumn{3}{|c|}{0.000} \\
\hline Toplam Açıklanan Varyans Değeri & \multicolumn{3}{|c|}{55.109} \\
\hline
\end{tabular}

Tablo 7'de görüleceği üzere KMO değerinin (0.887) ve Barlett küresellik testi sonucunun anlamlı olması $(0.00<0.05)$ örneklemin faktör analizi için yeterliliğini belirtmektedir. Ölçekten 
kusurlu görülen 2 ifade "TFF'yi bırakmayı düşündürecek seçeneğim neredeyse hiç yok gibi” ve "TFF'de çallşmaya devam etmek için hiçbir zorunluluk hissetmiyorum" çıkarılıp faktör analizi birkaç defa daha tekrar edilerek çalışmanın amacına en uygun olacak şekilde gerçekleşen faktör yapısına ulaşılmaya çalışılmıştır. Yapılan faktör analizi sonucunda ifadeler 3 boyutta toplanmıştır. Faktör 1: Duygusal bağlılık boyutunu, Faktör 2: Devam bağlılı̆̆1 boyutunu, Faktör 3: Normatif bağlılık boyutunu ifade etmektedir. Ölçeğin açıklanan varyans değerinin 55.109 olduğu belirlenmiştir.

Tablo 8. Hakem Öz Yeterlik Ölçeği Faktör Analizi Sonuçları

\begin{tabular}{|c|c|c|c|c|c|}
\hline İfadeler & $\begin{array}{c}\text { Faktör } \\
1\end{array}$ & $\begin{array}{c}\text { Faktör } \\
\mathbf{2} \\
\end{array}$ & $\begin{array}{c}\text { Faktör } \\
\mathbf{3} \\
\end{array}$ & $\begin{array}{c}\text { Faktör } \\
4 \\
\end{array}$ & $\begin{array}{c}\text { Faktör } \\
5\end{array}$ \\
\hline "Fiziksel yapım hakemliğe uygundur" & .490 & & & & \\
\hline "Kondisyonum müsabaka yönetmek için yeterlidir" & .857 & & & & \\
\hline "Sürat yeteneğim müsabaka yönetmek için yeterlidir" & .869 & & & & \\
\hline $\begin{array}{l}\text { "Fiziksel dayanıklılık düzeyim müsabaka yönetmek } \\
\text { için yeterlidir", }\end{array}$ & .849 & & & & \\
\hline $\begin{array}{l}\text { "Fiziksel kuvvet düzeyim müsabaka yönetmek için } \\
\text { yeterlidir" }\end{array}$ & .835 & & & & \\
\hline $\begin{array}{l}\text { "Hakemliğini yaptı̆̆ım branşın temel oyun } \\
\text { stratejilerini anlayabilirim" }\end{array}$ & & .443 & & & \\
\hline "Oyunun tüm kurallarını bilirim" & & .868 & & & \\
\hline "Uygun hakem mekaniğini anlayabilirim” & & 666 & & & \\
\hline "Rekabet sirasinda kritik kararlar verebilirim" & & & .631 & & \\
\hline "Kararlarımın arkasında dururum" & & & .543 & & \\
\hline "Çabuk karar verebilirim" & & & .557 & & \\
\hline "Oyuncuların baskisindan etkilenmem" & & & & .806 & \\
\hline "Seyircilerin baskısindan etkilenmem" & & & & .835 & \\
\hline "Antrenörlerin baskisindan etkilenmem" & & & & .804 & \\
\hline "Antrenörlerle etkili iletişim kurabilirim" & & & & & .736 \\
\hline "Diğer hakemlerle etkili iletişim kurabilirim" & & & & & .807 \\
\hline "Oyuncularla etkili iletişim kurabilirim" & & & & & .812 \\
\hline $\begin{array}{l}\text { "Oyundaki diğer görevlilerle etkili iletişim } \\
\text { kurabilirim" }\end{array}$ & & & & & .822 \\
\hline KMO Değeri & \multicolumn{5}{|c|}{.930} \\
\hline Barlett Küresellik Testi & \multicolumn{5}{|c|}{3554.377} \\
\hline Anlamlılık & \multicolumn{5}{|c|}{0.000} \\
\hline Toplam Açıklanan Varyans Değeri & \multicolumn{5}{|c|}{70.836} \\
\hline
\end{tabular}

Tablo 8'de görüleceği üzere KMO değerinin (0.930) ve Barlett küresellik testinin anlamlı olması $(0.00<0.05)$ örneklemin faktör analizi için yeterliliğini nitelemektedir. Yapılan faktör analizi neticesinde ifadeler 5 boyutta toplanmıştır. Faktör 1: Fiziksel yeterlik boyutunu, Faktör 
2: Oyun bilgisi boyutunu, Faktör 3: Karar verme boyutunu, Faktör 4: Baskı boyutunu, Faktör 5: İletişim boyutunu ifade etmektedir. Ölçeğin açıklanan varyans değerinin 70.836 olduğu belirlenmiştir.

\subsection{Hipotez Testlerine İlişkin Bulgular}

Tablo 9. Korelasyon Analizi Sonuçları

\begin{tabular}{|c|c|c|c|c|c|c|c|}
\hline Değişkenler & Ort. & S.S. & Cronbach Alfa & $\mathbf{1}$ & $\mathbf{2}$ & $\mathbf{3}$ \\
\hline ZD (1) & 3.526 & 0.429 & 0.627 & $\mathrm{r}$ & 1 & & \\
\cline { 4 - 8 } & & & & $\mathrm{p}$ & & & \\
\hline ÖB (2) & 3.389 & 0.587 & 0.825 & $\mathrm{r}$ & $0.477^{* *}$ & 1 & \\
\hline HÖYÖ (3) & 4.394 & 0.580 & 0.948 & $\mathrm{r}$ & $0.203^{* *}$ & $0.345^{* *}$ & 1 \\
\hline & & & & $\mathrm{p}$ & 0.000 & 0.000 & \\
\hline
\end{tabular}

$* * \mathrm{P}<0.01$ düzeyinde anlaml1, $* \mathrm{P}<0.05$ düzeyinde anlaml1

Tablo 9'da görüleceği üzere değişkenlere ait ortalama değerlere, standart sapma, cronbach alfa katsayılarına ve pearson korelasyon katsayılarına yer verilmiştir. Zihinsel dayanıklılık ve örgüte bağlılık değişkenleri arasındaki ilişki incelendiğinde zihinsel dayanıklılık ve örgüte bağlılık arasında pozitif yönlü anlamlı ilişki bulunmuştur $(r=0.477 ; p=0.000<0.05)$. Zihinsel dayanıklılık ve hakem öz yeterlik değişkenleri arasındaki ilişki incelendiğinde zihinsel dayanıklılık ve hakem öz yeterliği arasında pozitif yönlü anlamlı ilişki saptanıştır $(\mathrm{r}=0.203$; $\mathrm{p}=0.000<0.05$ ). Hakem öz yeterlik ve örgüte bağlılık değişkenleri arasındaki ilişki incelendiğinde hakem öz yeterlik ve örgüte bağlılık arasında pozitif yönlü anlamlı ilişki belirlenmiştir $(\mathrm{r}=0.345 ; \mathrm{p}=0.000<0.05)$.

Tablo 10. Regresyon Analizi Sonuçları

\begin{tabular}{|c|c|c|c|c|c|c|c|c|c|}
\hline $\begin{array}{c}\text { Bağımlı } \\
\text { Değişken }\end{array}$ & $\begin{array}{l}\text { Bağımsızı } \\
\text { Değișken }\end{array}$ & B & $\begin{array}{l}\text { Std. } \\
\text { Hata }\end{array}$ & $\begin{array}{l}\text { Std. } \\
\text { Beta }\end{array}$ & $\mathbf{t}$ & $\mathbf{p}$ & $\mathbf{F}$ & p & $\mathbf{R}^{2}$ \\
\hline \multirow{2}{*}{$\begin{array}{c}\text { HÖYÖ } \\
\text { (Model 1) }\end{array}$} & Sabit & 61.481 & 5.600 & & 10.978 & 0.000 & \multirow[t]{2}{*}{10.034} & \multirow[t]{2}{*}{0.000} & \multirow[t]{2}{*}{0.041} \\
\hline & ZD & 0.353 & 0.111 & 0.203 & 3.168 & 0.002 & & & \\
\hline \multirow{2}{*}{$\begin{array}{c}\text { ÖB } \\
\text { (Model 2) }\end{array}$} & Sabit & 19.198 & 5.087 & & 3.774 & 0.000 & \multirow[t]{2}{*}{68.544} & \multirow[t]{2}{*}{0.000} & \multirow[t]{2}{*}{0.227} \\
\hline & ZD & 0.838 & 0.101 & 0.477 & 8.279 & 0.000 & & & \\
\hline \multirow{2}{*}{$\begin{array}{c}\text { ÖB } \\
\text { (Model 3) }\end{array}$} & Sabit & 33.437 & 4.964 & & 6.736 & 0.000 & \multirow[t]{2}{*}{31.395} & \multirow[t]{2}{*}{0.000} & \multirow[t]{2}{*}{0.119} \\
\hline & HÖYÖ & 0.349 & 0.062 & 0.345 & 5.603 & 0.000 & & & \\
\hline \multirow{3}{*}{$\begin{array}{c}\text { ÖB } \\
\text { (Model 4) }\end{array}$} & Sabit & 3.126 & 6.014 & & 0.520 & 0.604 & \multirow{3}{*}{47.684} & \multirow{3}{*}{0.000} & \multirow{3}{*}{0.291} \\
\hline & ZD & 0.746 & 0.099 & 0.424 & 7.516 & 0.000 & & & \\
\hline & HÖYÖ & 0.261 & 0.057 & 0.258 & 4.577 & 0.000 & & & \\
\hline
\end{tabular}

Tablo 10'da görüleceği üzere Model 1'de zihinsel dayanıklılığın hakem öz yeterliğine etkisini belirleyebilmek için gerçekleştirilen regresyon analizi incelendiğinde oluşturulan modelin anlamlı olduğu belirlenmiştir $(\mathrm{F}=10.034 ; \mathrm{p}<0.05)$. Zihinsel dayanıklılığın hakem öz yeterliği değişkeninde meydana gelen değişimin \%4.1'ini (R2=0.041) açıkladığ1 görülmektedir. Zihinsel dayanıklılık puanının modeldeki katsayısı anlamlıdır $(\mathrm{p}<0.05)$. Zihinsel dayanıklılık 
hakem öz yeterliğine pozitif etki yapmaktadır (Std. Beta=0.203). Zihinsel dayanıklılık hakem öz yeterliği üzerinde bir artışa neden olmaktadır. Bu bulgular doğrultusunda; H1: "Zihinsel dayanıklılığın hakem öz yeterliği üzerinde pozitif bir etkisi vardır." hipotezi kabul edilmiştir.

Model 2'de zihinsel dayanıklılığın örgüte bağlılığa etkisini belirleyebilmek için gerçekleştirilen regresyon analizi incelendiğinde oluşturulan modelin anlamlı olduğu belirlenmiştir $(\mathrm{F}=68.544 ; \mathrm{p}<0.05)$. Zihinsel dayanıklılı̆̆ın örgüte bağlılık değişkeninde meydana gelen değişimin \%22.7'sini $(\mathrm{R} 2=0.227)$ açıkladığ́ görülmektedir. Zihinsel dayanıklılık puanının modeldeki katsayısı anlamlıdır $(\mathrm{p}<0.05)$. Zihinsel dayanıklılık örgüte bağlılığa pozitif etki yapmaktadır (Std. Beta=0.477). Zihinsel dayanıklılık örgüte bağlılık üzerinde bir artışa neden olmaktadır. $\mathrm{Bu}$ bulgular doğrultusunda; H2: "Zihinsel dayanıklılığın örgüte bağlılık üzerinde pozitif bir etkisi vardır." hipotezi kabul edilmiştir.

Model 3'te hakem öz yeterliğinin örgüte bağlılığa etkisini belirleyebilmek için gerçekleştirilen regresyon analizi incelendiğinde oluşturulan modelin anlamlı olduğu tespit edilmiştir $(\mathrm{F}=31.395 ; \mathrm{p}<0.001)$. Hakem öz yeterliğinin örgüte bağlılık değişkeninde meydana gelen değişimin \%11.9'unu (R2=0.119) açıkladığı görülmektedir. Hakem öz yeterlik puanının modeldeki katsayısı anlamlıdır $(\mathrm{p}<0.001)$. Hakem öz yeterliğinin örgüte bağlılığa pozitif etki yapmaktadır (Std. Beta=0.203). Hakem öz yeterliği örgüte bağlllık üzerinde bir artışa neden olmaktadır. Bu bulgular doğrultusunda; H3: "Hakem öz yeterliğinin örgüte bağlılık üzerinde pozitif bir etkisi vardır." hipotezi kabul edilmiştir.

Model 4'te zihinsel dayanıklılık ile aracı değişken olarak belirlenen hakem öz yeterliği değişkeninin örgüte bağlılık üzerindeki etkisi basit regresyon analizi ile incelenmiştir. Hakem öz yeterliğinin aracı değişken etkisinden bahsedebilmemiz için tüm aşamalardaki sonuçların birlikte değerlendirilmesi gereklidir. Bu bağlamda basit regresyon analizi sonucunda Model 1, Model 2 ve Model 3'te değişkenler arasında istatistiksel olarak anlamlı bir etki bulunmuş olup Model 4'e geçilmiştir. Zihinsel dayanıklılığın hakem öz yeterliği üzerinde pozitif yönde anlamlı bir etkisinin olduğu (Std. Beta $=0.203, \mathrm{t}=3.168, \mathrm{p}=0.000)$ ve zihinsel dayanıklılığın örgüte bağlılık üzerinde pozitif yönde anlamlı bir etkisinin olduğu (Std. Beta=0.477, t=8.279, $\mathrm{p}=0.000$ ) tespit edilmiştir. Hakem öz yeterliğinin (aracı değişken) modele dâhil edilmesiyle beraber zihinsel dayanıklılığın (bağımsız değişken) örgüte bağlılık (bağımlı değişken) üzerindeki etkisi Std. Beta=0.477; $\mathrm{p}=0.000$ değerinden Std. Beta $=0.424 ; \mathrm{p}=0.000$ değerine azalarak istatistiksel olarak anlamlı etkisi devam etmektedir. Bu bağlamda zihinsel dayanıklılık ile örgüte bağlılık üzerindeki etkide hakem öz yeterliğinin "kısmi aracılık" rolü üstlendiği sonucuna varılmıştır. Bu bulgular doğrultusunda; H4: "zihinsel dayanıklılığın örgüte bağlılık üzerindeki etkisinde öz yeterliğinin aracılık rolü vardır.” hipotezi kabul edilmiştir.

Son olarak aracı değişken etkisi Sobel (1982) testi ile incelenmiştir. Bu hususta $\mathrm{z}$ değerinin anlamlı olabilmesi için 1.96'dan büyük bir değer alması gerekmektedir. Yapılan test doğrultusunda aracılık etkisinin anlamlı $(\mathrm{z}=5.88$; $\mathrm{p}<0.001)$ olduğu görülmüştür.

\section{SONUÇ ve ÖNERILER}

“Organizational commitment” kavramı Türkçe yazında genelde örgütsel bağlılık şeklinde karşımıza çıkmaktadır. Kavramın gerçek anlamı gereğince bu çalışmada tercihen örgüte bağlılık ifadesi kullanılmıştır. Zira kavrama adını veren bağlılığın, örgütsel bir durumu değil bireyin örgüte yönelik bağlılığını ifade ettiği düşünülmektedir. Araştırmanın değişskenleri olan 
zihinsel dayanıklılık, örgüte bağlılık ve öz yeterlik kavramlarını bir arada inceleyen bir çalışmaya rastlanmamış olması bu çalışmanın özgün yanıdır ancak diğer yandan araştırma sonuçlarının karşılaştırılması ve tartışılması bakımından sınırlılık oluşturduğu da ortadadır.

$\mathrm{Bu}$ araştırmanın amacı, futbol hakemlerinin zihinsel dayanıklılık ve örgüte bağlılık ilişkisinde öz yeterliğin aracılık rolünü incelemektir. Hakemlerin demografik ve sosyal özellikleri incelendiğinde öne çıkan birçok bulgu bulunmaktadır. Futbol hakemlerinin cinsiyet dağılımına göre \%89.4'ü erkek, \%10.6'sı ise kadındır. Bu durum futbolda erkek egemenliğinin var olması ve kadın hakemlerin futbolda yeni yer bulmaları şeklinde yorumlanabilir. Yaşanılan yer değişkenine göre dağılımda hakemlerin \%29.4'ünün büyükşehirde, \%48.5'inin ilde, \%22.1'inin ise ilçede yaşamını sürdürdüğü görülmektedir. Büyükşehirde ve ilde yaşayan hakemlerin küçük yerleşim yerlerinde yaşayan hakemlere kıyasla birçok olanaklara ve alternatiflere sahip olmaları örgüte bağlılıklarını arttıran bir unsur olarak değerlendirilebilir. Ailede hakem olma durumuna göre dağılımda \%16.2'sinin ailesinde hakem olduğu, \%83.8'inin ise ailesinde hakem olmadığ 1 görülmektedir. Hakemlik topluluğunda baba-oğul, ağabey-kardeş ilişkisi bulunan hakemlerin varlığı bilinmektedir. Aile ve yakın çevrede (baba, amca, kardeş vb.) bir hakemin olması bireyin hakemlik sürecini kolaylaştırıcı, yol gösterici ve kariyerini hızlandırıcı bir unsur olarak değerlendirilebilir.

Yapılan korelasyon analizi sonucunda, zihinsel dayanıklılık ve örgüte bağlılık değişkenleri arasındaki ilişki incelenmiştir. Zihinsel dayanıklılık ve örgüte bağlılık arasında pozitif yönlü anlamlı ilişski bulunmuştur $(\mathrm{r}=0.477 ; \mathrm{p}=0.000<0.05)$. Zihinsel dayanıklılık ve hakem öz yeterlik değişkenleri arasındaki ilişki incelendiğinde zihinsel dayanıklılık ve hakem öz yeterlik arasında pozitif yönlü anlamlı ilişki belirlenmiştir $(r=0.203 ; p=0.000<0.05)$. Hakem öz yeterlik ve örgüte bağlılık değişkenleri arasındaki ilişki incelendiğinde hakem öz yeterlik ve örgüte bağlılık arasında pozitif yönlü anlamlı ilişki saptanmıştır $(r=0.345 ; \mathrm{p}=0.000<0.05)$.

Alanyazını incelendiğinde zihinsel dayanıklılık ve öz yeterlik değişkenleri arasında pozitif yönlü anlamlı bir ilişkinin bulunduğu birçok çalışma mevcuttur (Middleton vd., 2004; Nicholls vd., 2011; Ghazarians, 2012). Bu çalışmalar çalışmamızın bulgularını destekler niteliktedir. Yazında öz yeterlik ve örgüte bağlılık değişkenleri arasında pozitif yönlü anlamlı bir ilişkinin olduğunu belirten çalışmalar bulunmaktadır (Staples vd., 1999; Ayık vd. 2015; Köybaşı, 2017; Yıldız ve Yılmaz, 2017). Bu çalışmalar çalışmamızın bulgularıyla benzerlik göstermektedir. Araştırmalar dâhilinde hakem öz yeterliği ile örgüte bağlılık arasındaki ilişkiyi inceleyen herhangi bir çalışmaya rastlanmamıştır.

Zihinsel dayanıklılığın hakem öz yeterliğine etkisini belirleyebilmek için uygulanan regresyon analizi sonucunda oluşturulan model istatistiksel olarak anlamlıdır. Zihinsel dayanıklılık hakem öz yeterliğine pozitif etki yapmaktadır. Zihinsel dayanıklılığın örgüte bağlılığa etkisini belirleyebilmek için gerçekleştirilen analiz sonucunda oluşturulan modelin istatistiksel olarak anlamlı olduğu belirlenmiştir. Zihinsel dayanıklılık örgüte bağlılığa pozitif etki yapmaktadır. Hakem öz yeterliğinin örgüte bağlılığa etkisini belirleyebilmek için gerçekleştirilen analiz sonucunda oluşturulan modelin istatistiksel olarak anlamlı olduğu tespit edilmiştir. Hakem öz yeterliğinin örgüte bağlılığa pozitif etki yapmaktadır. Zihinsel dayanıklılık ile aracı değişken olarak belirlenen hakem öz yeterliği değişkeninin örgüte bağlılık üzerindeki etkisi basit regresyon analizi ile belirlenmiştir. Hakem öz yeterliğinin aracı değişken etkisinden bahsedebilmemiz için tüm aşamalardaki sonuçların birlikte değerlendirilmesi gereklidir. Hakem öz yeterliğinin (aracı değişken) modele dâhil edilmesiyle beraber zihinsel dayanıklılığın (bağımsız değişken) örgüte bağlılık (bağımlı değişken) üzerindeki etkisi (Std. Beta=0.477) değerinden (Std. Beta=0.424) değerine azalarak istatistiksel olarak anlamlı etkisi devam etmektedir. Bu bağlamda zihinsel dayanıklılık ile 
örgüte bağl1lık üzerindeki etkide hakem öz yeterliğinin "kısmi aracılık" rolü üstlendiği sonucuna varılmıştır. Son olarak aracı değişken etkisi Sobel (1982) testi ile incelenmiştir. Bu hususta $\mathrm{z}$ değerinin anlamlı olabilmesi için 1.96'dan büyük bir değer alması gerekmektedir. Gerçekleştirilen test sonucunda aracılık etkisinin anlamlı $(\mathrm{z}=5.88 ; \mathrm{p}<0.001)$ olduğu görülmüştür.

Maç ücretlerinin yetersizliği, vicdani sorumluluğun bir baskı unsuru oluşturması, il hakem kurulu nezdinde beklenen ilgiyi görememe, yalnızlık algısına kapılma, hem fiziksel hem de psikolojik olarak tükenme, yıpranma payı alamama, mesleğin kariyer firsatı açısından geleceğine inanmama ve haksız eleştiriler hakemlerin zihinsel dayanıklılı̆̆ını ve örgüte bağlılığını olumsuz anlamda etkileyebilir. Nihai olarak araştırmanın amacına ulaştığı söylenebilir.

$\mathrm{Bu}$ araştırmanın bazı kısıtları bulunmaktadır. Bu kısıtlar; araştırmanın kesitsel olması diğer bir ifadeyle tek bir zaman diliminde uygulanması, anket çalışmasının Antalya, Burdur ve Isparta illeriyle sınırlandırılması, federasyonun sadece il hakemi ve aday hakemlere yönelik izin vermesi olarak ifade edilebilir.

Araştırmada elde edilen bulguların literatüre önemli katkıları bulunmaktadır. İlk olarak araştırmanın modeli bakımından yazına farklı bir katkısı olmuştur. Yazında zihinsel dayanıklılık ve hakem öz yeterliğine ilişkin kısıtlı modeller ve araştırmalar yer almaktadır. Zihinsel dayanıklılık, örgüte bağlılık ve hakem öz yeterliği değişkenlerini aynı modelde incelemesi bakımından yazına farklı bir bakış açısı kazandırmıştır. İkinci olarak hakem öz yeterliğinin aracılık rolüne ilişkin literatürde bir boşluk bulunmaktadır. Zihinsel dayanıklılık ve örgüte bağlılık ilişkisinde öz yeterliğin kısmi aracılık rolünün bulunması başka değişkenlerin aracılık etkisinin bulunabileceğine işaret etmektedir. $\mathrm{Bu}$ bakımından gelecekteki çalışmalarda farklı değişkenlerle aracılık rolünün test edilmesinin gerektiği düşünülmektedir.

Araştırmada yapılan çıkarımlarla uygulamacılara ve araştırmacılara yol gösterici nitelikte önerilere şu şekilde ifade edilebilir:

- Kadın hakemlerin öz yeterliklerinin düşük olmasının nedenleri araştırılmalı, farklı değişkenler ile yeniden ölçülmelidir.

- Hakemlerin öz yeterliklerini geliştirmeleri için antrenman programlarını geliştirmeleri, ekstra antrenman yapmaları, aile yaşantısına dikkat etmeleri, düzenli beslenmeleri, alkol ve sigara gibi kötü alışkanlıklardan kaçınmaları tavsiye edilebilir.

- Hakemlerin zihinsel dayanıklılıklarını artırmak için belli dönemlerde ilgili kurullar tarafından psikolojik destek bağlamında çeşitli eğitim programları planlanmalıdır.

- Hakemlerin sezon içerisinde yaşadıkları stresi atmak adına sosyal faaliyetler (örneğin; yemek organizasyonları, dış etkinlikler, gezi, sportif faaliyetler, sinema gösterimi vb.) düzenlenmelidir.

- Hakemlerin antrenman koşulları ve stadyumlardaki hakemler için ayrılan alanlar iyileştirilmelidir.

- Hakemlerin öz yeterliklerini arttırıcı uygulamalar yapılarak (hakemlere mentör uygulaması, video analizler, stres ve baskı altında karar verme eğitimi, etkili iletişim eğitimi vb.) mesleki vizyonları ve mesleki yeterlikleri geliştirilebilir.

- TFF 5. Bölge'de faaliyet gösteren faal futbol hakemleri üzerine yapılan bu çalışmanın 
alanı genişletilebilir.

- Aracılık etkisi farklı değişkenler ile incelenebilir.

- Hakem öz yeterliği, örgütsel vatandaşlık ve kişilik özellikleri arasındaki ilişkiye yönelik araştırmalar yapılabilir.

- Hakemlerin örgüte bağlılıkları ile iş - aile çatışması arasındaki ilişkiye yönelik araştırmalar yapılabilir.

\section{KAYNAKÇA}

AKÇAKANAT, T., ERHAN, T., \& UZUNBACAK, H. H. (2019). Meslek Aşkının İş Tatmini Üzerine Etkisi: Akış Deneyiminin Aracı Rolü. İzmir Katip Çelebi Üniversitesi İktisadi ve İdari Bilimler Fakültesi Dergisi, 2(1), 84-99.

AKIL, C. (2007). Dayanıklılık Sporcularında Beslenme Bilgi Düzeylerinin Belirlenmesi. Selçuk Üniversitesi, Sağlık Bilimleri Enstitüsü, Yayımlanmamış Doktora Tezi, Konya.

AKMAN, D. (2019). Yetişkin Sporcuların İmgeleme, İçsel Konuşma ve Stresle Başa Çıkma Biçimlerinin Zihinsel Dayanıklılık İle İlişkisinin İncelenmesi. Marmara Üniversitesi Sağlık Bilimleri Enstitüsü, Yayımlanmamış Yüksek Lisans Tezi, İstanbul.

ALLEN, N. J., \& MEYER, J. P. (1990). The Measurement and Antecedents of Affective, Continuance and Normative Commitment to the Organization, Journal of Occuptional Psychology, 63(1), 1-18.

ALTINTAŞ, A. (2015). Sporcuların Zihinsel Dayanıklılıklarının Belirlenmesinde Optimal Performans Duygu Durumu, Güdülenme Düzeyi ve Hedef Yöneliminin Rolü. Ankara Üniversitesi Sağlık Bilimleri Enstitüsü, Yayımlanmamış Doktora Tezi, Ankara.

ALTINTAŞ, A., \& KORUÇ, P. (2016). Sporda Zihinsel Dayanıklılık Envanteri'nin Psikometrik Özelliklerinin İncelenmesi. Hacettepe Journal of Sport Science, 27(4), 162-171.

ATÍLLA GÖK, G. (2016). Bir Bağl1lık Pratiği Olarak Örgütsel Sessizlik. Yönetim ve Ekonomi Araştırmaları Dergisi, 14(1), 104-124.

AYDIN, F. (2018). Ankara İlindeki Profesyonel Kadın ve Erkek Futbol Takımlarının Öz Yeterlik ve Sargınlık Algıları Arasındaki İlişki. Ankara Üniversitesi Sağlık Bilimleri Enstitüsü, Yayımlanmamış Yüksek Lisans Tezi, Ankara.

AYIK, A., SAVAŞ, M., \& YÜCEL, E. (2015). İlkokullarda Görev Yapan Okul Müdürlerinin Genel Öz Yeterlik ile Örgütsel Bağlılık Algıları Arasındaki İlişkinin İncelenmesi. Uşak Üniversitesi Sosyal Bilimler Dergisi, 8(2), 193-218.

BANDURA, A. (1995). Self-Efficacy in Changing Societies, Cambridge University Press.

BARON, R. M., \& KENNY, D. A. (1986). The Moderator-mediator Variable Distinction in Social Psychological Research: Conceptual, Strategic and Statistical Considerations. Journal of Personality and Social Psychology, 51(6), 1173-1182. 
BAYKÖSE, N., \& KESKİN, P. (2018). Boşluğa Dokunmak Filminin İçerik Açısından Sporda Psikolojik Beceri Faktörleri Bağlamında İncelenmesi. Ulusal Spor Bilimleri Dergisi, 2(1), 43-53.

BAYRAM, A., ÇETINKAYA, G., \& YILDIRIM, Y. (2020). Hakemlerde Öz Yeterlilik, Örgütsel Sessizlik ve Yaşam Doyumu Arasındaki İlişkinin İncelenmesi. Spor ve Performans Araştırmaları Dergisi, 11(1), 24-34.

CEYLAN, T., EGEMEN, E., CEYLAN, L., \& ERİLLI, N.A. (2017). Futbol Hakemlerinin Sargınlık ve Öz Yeterlilik Düzeylerinin İncelenmesi. Dünya Spor Bilimleri Araştırmaları Kongresi, Manisa, Türkiye.

CLOUGH, P. J., EARLE, K., \& SEWELL, D. (2002). Mental Toughenss: The Concept and its Measurement. In I. Cockerill (Ed.), Solution in Sport Psychology, 32-43.

CONNAUGHTON, D., WADEY, R., HANTON, S., \& JONES, G. (2008). The Development and Maintenance of Mental Toughness: Perceptions of Elite Performers. Journal of Sports Sciences, 26(1), 83-95.

DİNÇ, M., UZUNBACAK, H. H., \& AKÇAKANAT, T. (2019). Örgütsel Nostaljinin İşten Ayrılma Niyeti Üzerine Etkisinde İşin Anlamlılığının Aracılık Rolü. Pamukkale Üniversitesi Sosyal Bilimler Enstitüsü Dergisi, 36, 349-369.

EKMEKÇİ, R., \& MIÇOOĞULLARI, B. O. (2017). Sporda Zihinsel Dayanıklılık Analizi: Futbol Hakemleri Örneği, 15. Spor Bilimleri Kongresi, Antalya, Türkiye.

ESKIYECEK, C. G., SATICI, Ö., ÖZALTAŞ, H. N., \& SAVUCU, Y. (2018). Yüzme Hakemlerinin Genel Öz-Yeterlik İnançlarının İncelenmesi. 6. Uluslararası Bilim, Kültür ve Spor Kongresi, Lviv, Ukrayna.

FELTZ, D. L., SHORT, S. E., \& SULLIVAN, P. J. (2008). Self-efficacy in Sport. Human Kinetics.

GHAZARIANS, M. (2012). Evaluating the MEBActive-Youth as Measure of Mental Toughness (Doctoral dissertation, University of Massachusetts Amherst).

GRAHAM, J., HANTON, S., \& CONNAUGHTON, D. (2002). What is This Thing Called Mental Toughness and Investigation of Elite Sport Performers. Journal Applied Sport Psychology, 14(3), 205-218.

GUILLÉN, F., \& FELTZ, D. L. (2011). A Conceptual Model of Referee Efficacy. Frontiers in Psychology, 25(2), 1-5.

GÜNCE, S. (2013). İlköğretim Okullarında Örgütsel Adalet ile Örgütsel Bağlılık İlişkisi. Harran Üniversitesi Sosyal Bilimler Enstitüsü, Yayımlanmamış Yüksek Lisans Tezi, Şanlıurfa.

GÜRBÜZ, S., \& ŞAHIN, F. (2017). Sosyal Bilimlerde Araştırma Yöntemleri, 4. Bask1, Ankara: Seçkin Yayıncılık.

HOŞ, C., \& OKSAY, A. (2015). Hemşirelerde Örgütsel Bağl1lık ile İş Tatmini İlişkisi. Süleyman Demirel Üniversitesi İktisadi ve İdari Bilimler Fakültesi Dergisi, 20(4), $1-24$.

KARAATLI, M. (2018). Güvenilirlik Analizi, Editör: Şeref Kalaycı, SPSS Uygulamalı Çok Değişkenli İstatistik Teknikleri, 8. Baskı, Ankara: Dinamik Akademi Yayın 
Dağıtım.

KARAÇAM, A., \& PULUR, A. (2017). Hakem Öz Yeterlik Ölçeği'nin (HÖYÖ) Türkçeye Uyarlama Çalışması. Niğde Üniversitesi Beden Eğitimi ve Spor Bilimleri Dergisi, 11(1), 118-128.

KARAÇAM A., \& PULUR, A. (2019). Hakemlerin Problem Çözme ile Öz Yeterlikleri Arasındaki İlişkinin İncelenmesi. Gaziantep Üniversitesi Spor Bilimleri Dergisi, 4(1), 115-130.

KARASAR, N. (2013). Bilimsel Araştırma Yöntemi, 25. Basım, Ankara: Nobel Yayın Dağıtım. Kayış, A. (2018). Güvenilirlik Analizi, Ed. Ş. Kalaycı, SPSS Uygulamalı Çok Değiş̧kenli İstatistik Teknikleri, 8. Baskı, Ankara: Dinamik Akademi Yayın Dağıtım.

KLINE, R. B. (2011). Principles and Practice of Structural Equation Modelling. NY: Guilford Press.

KOÇAK, M., ÖZBAŞ, A. A., \& GÜRHAN, H. (2017). Beden Eğitimi ve Spor Öğrencilerinin Psikolojik Sağlamlık ve Öz Yeterlik Düzeyinin Belirlenmesi. Niğde Üniversitesi Beden Eğitimi ve Spor Bilimleri Dergisi, 11(2), 129-135.

KÖYBAŞI, F., \& DÖNMEZ, B. (2017). Okul Yöneticilerinin Girişimcilik, Öz-Yeterlik ve Örgütsel Bağlılık Algılarının Analizi. Kuram ve Uygulamada Eğitim Yönetimi, 23(2), 249-280.

LUTHANS, F. (2002). Positive Organizational Behavior: Developing and Managing Psychological Strenghts. Academy of Management Perspectives, 16(1), 57-72.

METE, M., ZINCİRKIRAN, M., TİFTIK, H., YALÇIN A., \& PEKCAN, A. (2015). Personel Güçlendirme, Örgütsel Bağlılık ve İş Memnuniyeti İlişkisinin Yapısal Eşitlik Modeli İle İncelenmesi Turizm Sektöründe Bir Araştırma, Bartın Üniversitesi Sosyal Bilimler Dergisi, 6(12), 137-156.

MEYER, J. P., \& ALLEN, N. J. (1991). A Three-Component Conceptualization of Organizational Commitment. Human Resource Management Review, 1(1), 61-89.

MIÇOOĞUllaRI, B. O., GÜMÜŞDAĞ, H., ÖDEK, U., \& BEYAZ, Ö. (2017). Comparative Study of Sport Mental Toughness between Soccer Officals. Universal Journal of Educational Research, 5(11), 1970-1976.

MIDDLETON, S. C., MARSH, H. W., MARTIN, A. J., RICHARDS, G. E., SAVIS, J., PERRY Jr., C., \& BROWN, R. (2004). The Psychological Performance Inventory: Is the Mental Toughness Test Tough Enough?. International Journal of Sport Psychology, 35(2), 91-108.

MORAN, A. (2004). Sport and Exercise Psychology: A Critical Introduction. Hove, England: Routledge.

MYERS, N. D., FELTZ, D. L., GUILLÉN, F., \& DITHURBIDE, L. (2012). Development of and Initial Validity Evidence for the Referee Self-Efficacy Scale: A Multistudy Report. Journal of Sport and Exercise Psychology, 34(6), 737-765.

NICHOLLS, A. R., LEVY, A. R., POLMAN, R. C., \& CRUST, L. (2011). Mental Toughness, Coping Self-efficacy, and Coping Effectiveness Among Athletes. 
International Journal of Sport Psychology, 42(6), 513-524.

ÖZDAŞLI, K., KANTEN, S., \& KANTEN, P. (2009). Yöneticilerin Kariyer İlerleme Arzusu ile Örgütsel Bağlılıklarının Akıl Hocalığı Eğilimlerine Etkisini Belirlemeye Yönelik Bir Araştırma, Süleyman Demirel Üniversitesi İktisadi ve İdari Bilimler Fakültesi Dergisi, 14(3), 229- 243.

ÖZŞAHIN, M., BAYARÇELİK, E. B., \& YILDIZ, B. (2017). Strateji Tipleri ile Yenilik Performansı İlişkisinde Stratejik Karar Verme Hızının Şartlı Değişken (Moderatör) Etkisi, Uluslararası İktisadi ve İdari İncelemeler Dergisi, 16. UİK Özel Sayısı, 749766.

PEKER, T. (2018). Öz-Yeterlik ile Yaşam Doyumu Arasındaki İlişkide Proaktif Kişiliğin Aracılık Rolü. Ordu Üniversitesi Sosyal Bilimler Enstitüsü, Yayımlanmamış Yüksek Lisans Tezi, Ordu.

SAKIZ, G. (2014). Özdüzenleme Öğrenmeden Öğretime Özdüzenleme Davranışlarının Gelişimi, Stratejiler ve Öneriler. Ankara: Nobel Akademik Yayıncılık.

SHEARD, M. (2013). Mental Toughness: The Mindset Behind Sporting Achievement. Second Edition, Hove, East Sussex: Routledge.

SHEARD, M., GOLBY, J., \& WERCH, A. V. (2009). Progress Toward Construct Validation of the Sports Mental Toughness Questionnaire (SMTQ). European Journal of Psychological Assessment, 25(3), 186-193.

SLACK, L. A., BUTT, J., MAYNARD, I., \& OLUSOGA, P. (2014). Understanding Mental Toughness in Elite Football Officiating: Perceptions of English Premier League Referees. Sport and Exercise Psychology Review, 10(1), 4-24.

SLACK, L. A., MAYNARD, I. W., BUTT, J., \& OLUSOGA, P. (2013). Factors Underpinning Football Officiating Excellence: Perceptions of English Premier League Referees. Journal of Applied Sport Psychology, 25(3), 298-315.

SAMUEL, R. D. (2015). A Psychological Preparation Framework for Elite Soccer Referees: A Practitioner's Perspective. Journal of Sport Psychology in Action, 6(3), 170-187.

SOBEL, M. E. (1982). Asymptotic Confidence Intervals for Indirect Effects in Structural Equation Models. Sociological Methodology, 13, 290-312.

STAPLES, D. S., HULlAND, J. S., \& HIGGINS, C. A. (1999). A Self-efficacy Theory Explanation for the Management of Remote Workers in Virtual Organizations. Organization Science, 10(6), 758-776.

TAYLOR, A. B., MACKINNON, D. P., \& TEIN, J. Y. (2007). Tests of Three-Path Mediated Effect. Organizational Research, 11(2), 241-269.

Türk Dil Kurumu (2020). "Bağl1lık”, http://www.sozluk.gov.tr, Erişim Tarihi: 25.07.2020

USHER, L. E., \& PAJARES, F. (2008). Sources of Self-Efficacy in School: Critical Review of the Literature and Future Directions, Review of Educational Research, 78(4), 751-796.

WASTI, A. (2000). Meyer ve Allen'in Üç Boyutlu Örgütsel Bağlılık Ölçeğinin Geçerlilik ve Güvenilirlik Analizi, 8. Ulusal Yönetim ve Organizasyon Kongresi, Nevşehir, 
Türkiye.

WOOD, R., \& Bandura, A. (1989). Social Cognitive Theory of Organizational Management. Academy of Management Review, 14(3), 361-384.

YAMANE, T. (2001). Temel Örnekleme Yöntemleri, 1.Baskı, (Çev: Alptekin Esin, M. Akif Bakır, Celal Aydın ve Esen Gürbüzsel), İstanbul: Literatür Yayıncılık.

YEŞILYAPRAK, B. (2002). Gelişim ve Öğrenme Psikolojisi. Ankara: Pegem A Yayıncılık. Yeşilyaprak, B. (2006). Gelişim ve Öğrenme Psikolojisi. Ankara: Pegem A Yayıncilik.

YILDIRIM, G., \& ATİLLA, G. (2020). Öz Yeterliğin Bilinçli Farkındalık ve Benlik Saygısına Etkisi. Eskişehir Osmangazi Üniversitesi Sosyal Bilimler Dergisi, 21(1), 59-84.

YILDIZ, A., \& ATİLLA, G. (2019). Örgütsel Adalet Algısının Örgütsel Bağlılık Düzeyine Etkisi: Otel Çalışanları Üzerinde Bir Araştırma, Bartın Üniversitesi İktisadi ve İdari Bilimler Fakültesi Dergisi, 10(19), 39-64.

YILDIZ, A. B., \& YILMAZ, B. (2017). Sporcularda Zihinsel Dayanıklılık ve Öz Yeterlik Düzeyleri Arasındaki İlişkinin İncelenmesi, 15. Uluslararası Spor Bilimleri Kongresi, Antalya, Türkiye.

YILDIZ, S. M. (2011). İçsel Pazarlama, İş Tatmini ve Örgütsel Bağlılık İlişkisi: Spor Okullarında Görev Yapan Antrenörler Üzerine Bir İnceleme. Selçuk Üniversitesi Beden Eğitimi ve Spor Bilim Dergisi, 13(2), 216-225.

YÜRÜR, S., \& KESER, A. (2010). İşe Bağlı Gerginlik ile İş Tatmini İlişkisinde Duygusal Tükenmenin Aracı Rolü. Ankara Üniversitesi SBF Dergisi, 65(4), 165-193. 